\title{
Mineraçãão
}

\section{Electroflotation of cassiterite fines using a hydrophobic bacterium strain}

\section{Eletroflotação de finos de cassiterita utilizando uma linhagem bacteriana hidrofóbica}

Lorgio Gilberto Valdiviezo Gonzales

Departamento de Engenharia de Materiais PUC-Rio.

lorgiovaldiviezo@gmail.com

\section{Gabriela Alejandra Huamán Pino \\ Departamento de Engenharia de Materiais PUC-Rio. \\ gabriela@esp.puc-rio.br}

\section{Maurício Leonardo Torem}

Departamento de Engenharia de Materiais PUC-Rio.

torem@puc-rio.br

\section{Resumo}

Nesse trabalho, é apresentada a eletroflotação de finos de cassiterita, utilizando-se o Rhodococcus opacus (R. opacus) como biorreagente. A avaliação da interação desse micro-organismo com a superfície do mineral foi realizada através de experimentos envolvendo medidas de potencial zeta, ângulo de contato e ensaios de adsorção. Adicionalmente, os efeitos da densidade de corrente e concentração de microorganismo no tamanho médio de bolhas (Sauter) foram também avaliados. Após a interação, foi observado um caráter hidrofóbico nas partículas, como verificado pela medida de ângulo de contato. Além disso, foram observadas mudanças na mobilidade eletroforética das partículas de cassiterita, para valores próximos de zero. O tamanho médio de bolhas, obtido através da técnica de difração laser, foi de $26 \mu \mathrm{m}$. A densidade de corrente e a concentração de bactérias mostraram-se como os parâmetros de maior influência no tamanho de bolhas. Os ensaios de eletroflotação constataram uma recuperação máxima em torno de $64,5 \%$, para uma concentração de bactéria de $2,87 \times 10^{12}$ células $/ \mathrm{mL}$ ( $50 \mathrm{mg}$ cells/L); densidade de corrente de $51,4 \mathrm{~mA} / \mathrm{cm}^{2}$ e pH 5,0.

Palavras-chave: Eletroflotação, finos de cassiterita, Rhodococcus opacus.

\begin{abstract}
In this work, the electroflotation of cassiterite fine ranges using Rhodococcus opacus ( $R$. opacus) as bioreagent has been carried out. The interaction between $R$. opacus and mineral surface was valued through the zeta potential, contact angles measurements and adsorption studies. Furthermore, studies were attempted to check the effect of current density and microorganism concentration on mean bubble size (Sauter). After the interaction, the resulting particles exhibited hydrophobic characters, as verified by the increase of the contact angle. Also, the electrophoretic mobilities of cassiterite particles showed a mean value close to zero after interaction with R. opacus. The measurement of bubble size by laser diffraction showed a mean bubble size of 26um. Current density and bacterial concentration seem to be the main parameters affecting the mean diameter of the bubbles. An electroflotation test reported recovery of around $64.5 \%$ at $\mathrm{pH} 5$, concentration of $2.87 \times 10^{12} \mathrm{cells} / \mathrm{ml}(50$ $\mathrm{mg} / \mathrm{L})$ and current density of $51.4 \mathrm{~mA} / \mathrm{cm}^{2}$.
\end{abstract}

Keywords: Electroflotation, cassiterite fines, Rhodococcus opacus. 


\section{Introduction}

The use of microorganisms in mineral beneficiation has been elucidated with the recent development in biotechnology; microorganisms and associated extracellular metabolic products are used to selectively separated gangue ores and have been reported as friendly modifiers, collectors and depressants (Govender \& Gericke, 2011; Didyk \& Sadowski, 2012).

Many studies have been focused on the mineral-bacteria interaction in order to understand the mechanisms behind the flotability and mineral selectivity achieved in the beneficiation process. These microorganisms, both living and dead, and products derived from the organisms are able to affect the surface characteristics and flotation behavior of the minerals. So,

\section{Materials and methods}

\section{Bacteria strain}

$R$. opacus obtained from the culture collection of the Tropical Foundation of Searches and Technology André Tosello - São Paulo, was used in this study. The bacterium was grown at $28^{\circ} \mathrm{C}$ in agitated liquid media containing, yeast extract, $3 \mathrm{~g} / \mathrm{L}$; peptone, $5 \mathrm{~g} / \mathrm{L}$; glucose, $10 \mathrm{~g} / \mathrm{L}$

\section{Mineral sample}

Mineral sample de cassiterite was obtained from Zé Estrada Mineração, MG, Brazil. The sample was properly ground and sieved for the experimental

\section{Electrokinetics experiments}

Zeta potential of the cassiterite was determined in the presence and absence of bacteria using a Malvern Zeta-sizer. The zeta potential of bacterial cells was measured at a concentration of 600 $\mathrm{mg} / \mathrm{L}\left(3,4 \times 10^{14}\right.$ cells $\left./ \mathrm{ml}\right)$. All measure-

\section{Adsorption studies}

In the adsorption experiments, $0.5 \mathrm{~g}$ of mineral sample was added to $50 \mathrm{ml}$ of cellular suspension with a known initial concentration of bacteria. The mixture was agitated in a mechanical shaker for 15 minutes at $150 \mathrm{rpm}$ and $28^{\circ} \mathrm{C}$ and subsequently they can function as flotation collectors and as flotation depressants and activators (Sharma, 2001; Natarajan, 2006; Rao \& Subramanian, 2007; Pecina et al., 2009).

Fine particles typically show slow recovery rates, owing to decreased particle-bubble collision efficiency. Moreover, very small particles tend to have large specific areas and low mass (Pease, 2006; Shahbazi et al., 2010; Miettinen et al., 2010). So, the treatment of mineral fines treatment continues to be one of the major technical challenges for the mineral processing area.

Studies have reported that the recovery of particles in the diameter range of $1-10 \mu \mathrm{m}$ is increased by decreasing bubble size, which is largely the result of the increased collision

and malt extract $3.0 \mathrm{~g} / \mathrm{L}$. The medium was sterilized by autoclaving at a pressure $1 \mathrm{~atm}$ for 20 minutes. The $\mathrm{pH}$ was adjusted to 7.2 with diluted $\mathrm{NaOH}$ solutions. Growth was allowed to proceed for $48 \mathrm{~h}$ on a horizontal shaker operating at $250 \mathrm{rpm}$. After microorganism growth,

test. The mean particle size $\left(\mathrm{d}_{50}\right)$ of the fine fraction $(-37 \mu \mathrm{m})$ was found to be $8 \mu \mathrm{m}$, using Malver mastersizer model 2000 particle size analyser. FRX analy-

ments were conducted at the same ionic strength $\left(10^{-3} \mathrm{M} \mathrm{NaCl}\right)$. To measure the zeta potential of cassiterite after interaction with bacteria, the sample was first conditioned with $R$. opacus under required conditions $(\mathrm{pH}$, adsorption

centrifuged at $200 \mathrm{rpm}$ for $3 \mathrm{~min}$ to settle the minerals. The bacterial concentration in the supernatant was determined using the optical density method. The concentration of bacteria adsorbed at the mineral surface was taken as the difference between the efficiency between the particles and the bubbles (Shahjahan Kaisar Alam Sakar et al., 2010; Chipfunhu et al., 2011).

Electroflotation has been suggested as the process for obtaining the smallest bubble diameters $(<60 \mu \mathrm{m})$, that involve oxidation-reduction reactions. Many applications have been developed with this technique, such as wastewater treatment and mineral processing, especially fine particles.

In this work, the electroflotation of fine cassiterite using $R$. opacus as bioreagent was investigated. The effects of solutions $p \mathrm{H}$, microorganism concentration and current density on flotation recovery and bubble size were studied in batch experiments. Furthermore, the mean bubble sizes were determined. the culture was separated by centrifugation, and the obtained solid material was washed with deionized water and suspended in $\mathrm{NaCl} 0.1 \mathrm{mM}$, later being sterilized at $1 \mathrm{~atm}$ of pressure during 20 $\min$. The cellular quantification was determined by dry weight.

sis confirmed the purity of mineral sample $(84.7 \%)$.

time and cell concentration) and then unattached cells were removed by centrifugation at $2000 \mathrm{rpm}$ for $3 \mathrm{~min}$. The cassiterite particles were resuspended in $10^{-3} \mathrm{M} \mathrm{NaCl}$ and the $\mathrm{pH}$ was readjusted to the initial value.

inoculated concentration of bacteria and the concentration of bacteria remaining in the supernatant after 15 min contact time. Adsorption studies were performed as a function of the $\mathrm{pH}$ values of the suspension with a $10^{-3} \mathrm{M}$ $\mathrm{NaCl}$ as a supporting electrolyte. 


\section{Contact angle measurements}

Contact angle on mineral powders was obtained by sorption measurement using Kruss Tensiometer K 100. The Washburn equation is used to measure the contact angle on powder samples. When a column of powder bed is in

\section{Bubble size measurement}

An electroflotation cell was constructed of acrylic material with $1 \mathrm{~L}$ of capacity operated in batch mode. A polished stainless steel with $8.5 \mathrm{~cm}$ of diameter and total surface area of 56.7 $\mathrm{cm}^{2}$ was used as cathode. It was placed in the bottom of the cell and $\mathrm{a} \mathrm{Ti} / \mathrm{RuO}_{2}$ mesh supplied by De Nora, Brazil, was used as anode ( $3 \mathrm{~mm}$ above the cathode.) This configuration has been chosen to measure

\section{Electroflotation experiments}

The electroflotation cell used in this work (Figure 1) is a modification of the Hallimond tube such as to incorporate the electrolytic cell directly below the flotation column. The arrangement and

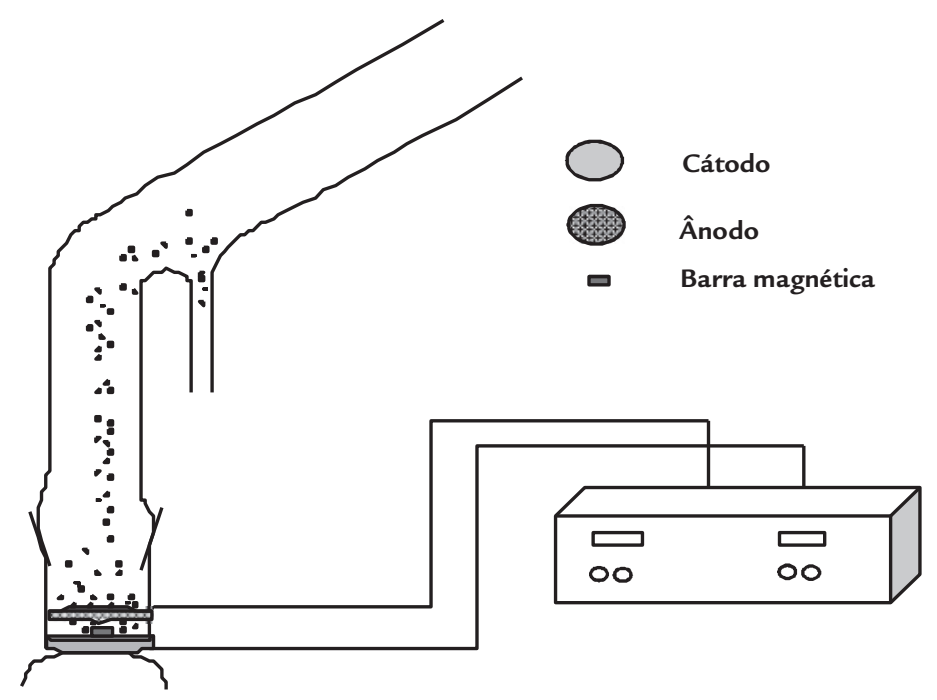

contact with liquid, the pores between the particles act like small capillaries and the rise of liquid is measurable. The capillary constant in the Washburn equation was determined using toluene and water respectively. Mineral

both the hydrogen and oxygen bubbles produced at the same time. The electrical current was applied using a TECTROL mod.-TCA-30-10XR1A DC power supply with a maximum current rating of $10 \mathrm{~A}$ at an open circuit potential of $30 \mathrm{~V}$. All experiments were performed at an ionic strength of $0.1 \mathrm{M} \mathrm{NaCl}$.

The micro-bubbles produced in the electrochemical cell were determined with electrode material were similar to those used for bubble sizes measurements. A magnetic stirrer bar was placed in the middle of electrodes to provide enough energy to maintain the ore suspension samples of $-210 \mu \mathrm{m}+106 \mu \mathrm{m}$ size fraction were used. A $2 \mathrm{~g}$ of mineral was placed into a glass sample tube and was carefully and equally packed each time. Each measurement was repeated at least 3 times.
Mastersizer 2000SM - equipment from Malvern Instruments, UK, through light scattering. This instrument is capable of analysis in the range from 0.1 to 2000 $\mu \mathrm{m}$. Pumping speed was kept low $(1000$ $\mathrm{rpm})$, to avoid undesired bubble formation through atmospheric air entrance. Analysis was started immediately, to avoid bubble coalescence or collapse imposed by shear. homogeneous. The pulp density was kept constant at $1 \%$, and $\mathrm{NaCl} 0.1 \mathrm{M}$ was used as electrolyte. The pulp was conditioned for two minutes. All flotation experiments were repeated twice.
Figure 1

Schematic diagram for electroflotation cell.

\section{Results and discussions}

\section{Electrokinetic experiments}

Figure 2 shows zeta potential curves for R. opacus and cassiterite (before and after interaction). The surface charge of $\mathrm{R}$. opacus decreased with decreasing $\mathrm{pH}$ and reached an IEP at $\mathrm{pH}$ 2.42. The IEP for cassiterite untreated is 5.9. According to this data, in the range between $\mathrm{pH}$ 2.42 to 5.8 an electrostatic interaction between $R$. opacus and cassiterite is expected to be favorable because of their different surface charges. It is interesting to note that the surface charge of cassiterite after conditioning with $R$. opacus, was close to zero. This may indicate that the adsorption of R. opacus cells onto cassiterite surface formed biocoagulates and the non-electrostatic forces, such as hydrogen bounding and chemical forces, may govern the $R$. opacus and cassiterite interaction.
Bacteria and yeast and products derived from them can be excellent biocoagulating agents and in some cases can function as selective coagulating agents. Kuyumcu et al. (2008) have demonstrated that Sacchharomyces cerevisiae and Yarrowia lipolytica are excellent coagulants for sphalerite and galena (below $10 \mu \mathrm{m}$ ). 
Figure 2

Zeta potential of $R$. Opacus and cassiterite particles (before interaction and after interaction with $R$. Opacus).

\section{Adsorption studies}

The amount of adhesion of $R$. opacus cells to cassiterite particles as a function of $\mathrm{pH}$ values is presented in Figure 3. It is evident that the adhered quantity of microorganisms increased in the acid region, where cassiterite and $R$. Opacus have different surface charges

Figure 3

Adsorption of bacterial cells onto cassiterite at different $\mathrm{pH}$ values.

\section{Contact angle measurements}

The effect of the microbial cellcassiterite interaction on the surface properties of the mineral was determined by measuring the contact angle of cassiterite sample before and after biomodification. Figure 4 shows the effect of bacterial adhesion in the contact angle of cassiterite as a function of initial bacteria concentration.

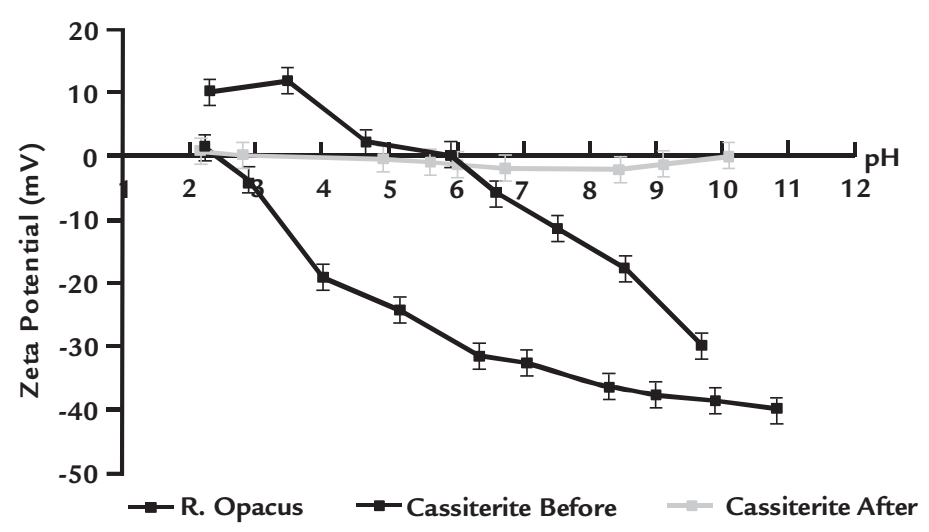

and consequently are highly subject to electrostatic interaction. However above the IEP of cassiterite, the non-electrostatic forces such as hydrogen bounding and chemical forces, may govern the adsorption process.

The effect of the initial bacteria con-

centration on the quantity of microorganism adsorbed onto cassiterite is depicted in the same figure. Even though the bacterial cells tended to adhere on mineral surface for all concentration tested, the quantity of microorganisms adsorbed increased with the initial microorganism concentration.

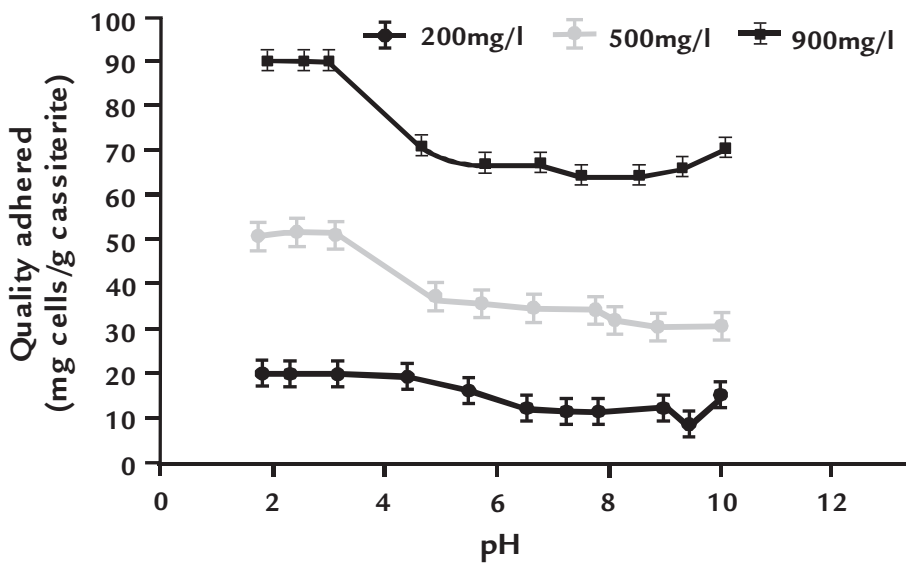

The $\mathrm{pH}$ value of 3 was chosen because the highest adsorption verified in the adsorption test. Before the interaction with the microorganism, the cassiterite surface was completely hydrophilic, since its affinity for the air bubble was completely nil (values of contact angle such as zero). After the interaction, a hydrophobic character was founded, as verified by the increase of the contact angle. So, prior to the interaction, the contact angle was $0^{\circ}$ (hydrophilic) and after conditioning with $34.47 \times 10^{12}$ cells $/ \mathrm{mL}$ ( $600 \mathrm{mg} / \mathrm{L}$ ), the contact angle increased to $80^{\circ}$.

Figure 4

Contact angle for cassiterite as a function of concentration of $R$. opacus, after conditioning with cells of $R$. Opacus, at $\mathrm{pH} 3$.

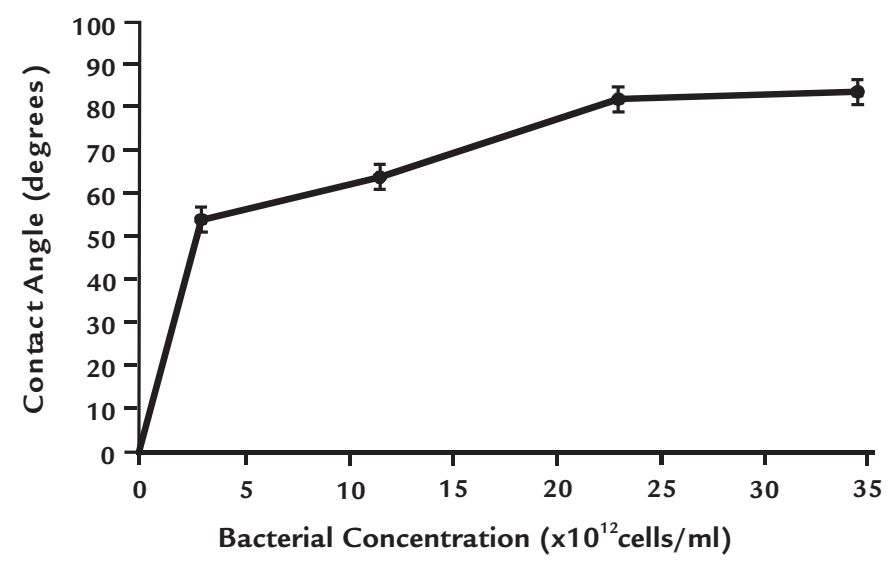




\section{Bubble size measurement}

The bubble size measurement was performed in the absence of mineral but it considered equivalent reagent concentration. Figure 5 shows the effect of $R$. opacus concentration and current density on mean bubble diameter. In the absence of microorganisms, big bubbles were formed, while for concentration greater than $2.87 \times 10^{12}$ cells $/ \mathrm{mL}$, the average bubble size decreased substantially (from
$45 \mu \mathrm{m}$ to $15 \mu \mathrm{m})$. These results indicated coalescence as the main mechanism determining the size.

Figure 5 also shows bubble size produced at different current densities. Within the range studies $\left(20-95 \mathrm{~mA} / \mathrm{cm}^{2}\right)$ high current density promotes the formation of small bubbles. In accordance with Shahjahan Kaisar Alam Sarkar et al (2010), more nucleation sites are expected to become active at higher current density as the solution adjacent to the electrode surface becomes more supersaturated (less amount of dissolved gas before detachment). As detachment time is less, fine bubbles are expected in the case of higher current densities. Finally, low current densities lead to large bubbles sizes and thus they should be avoided to prevent non-effective electroflotation separations.

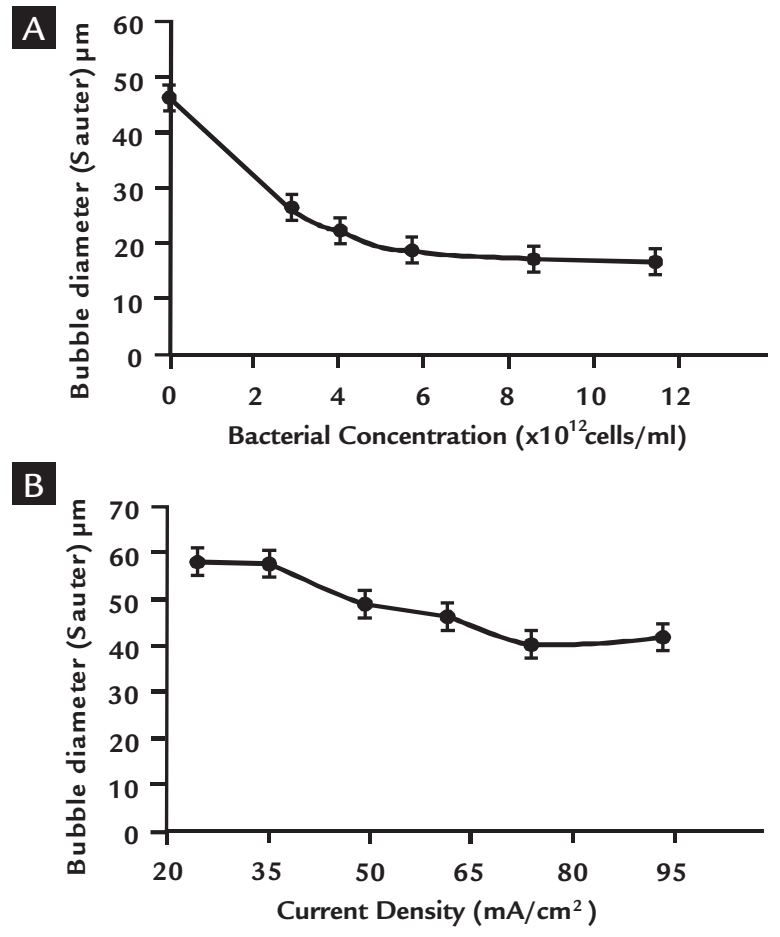

\section{Electroflotation experiments}

Since $R$. opacus cells have hydrophobic properties and can easily adsorb onto cassiterite surface under acid conditions, we investigate the use of $R$. opacus as collector or surface modifier for cassiterite electroflotation. The electroflotation of fine cassiterite as a function of bacterial concentration in the absence of a conventional collector is presented in Figure 6. Experiments were carried out at $\mathrm{pH} 3$ in the presence of $0.1 \mathrm{M} \mathrm{NaCl}$ for a conditioning time of $5 \mathrm{~min}$ and flotation time of $6 \mathrm{~min}$. The highest flotation recovery of $64.5 \%$ was observed with a $2.87 \times 10^{12}$ cells $/ \mathrm{mL}(50$ $\mathrm{mg}$ cells/L) of initial bacterial concentration, which decreased to $50 \%$ when the $R$. opacus concentration increased. This decreased recovery could be the result of very large flocs that formed
Figure 5

Bubble size as a function of:

A) Concentration of $R$. opacus.

B) Current density, at $\mathrm{pH} 5$. and could not be levitated by the fine bubbles produced. Such behaviors have been reported in literature (Dubel et al., 1992 and Botero, 2007).

The observed average recovery of cassiterite is similar that of Quin Wen-Quing et al (2012), who reported recoveries of $62 \%$ using a mixer of salicylhydroxamic acid and tributyl phosphate collectors in fine cassiterite electroflotation system.

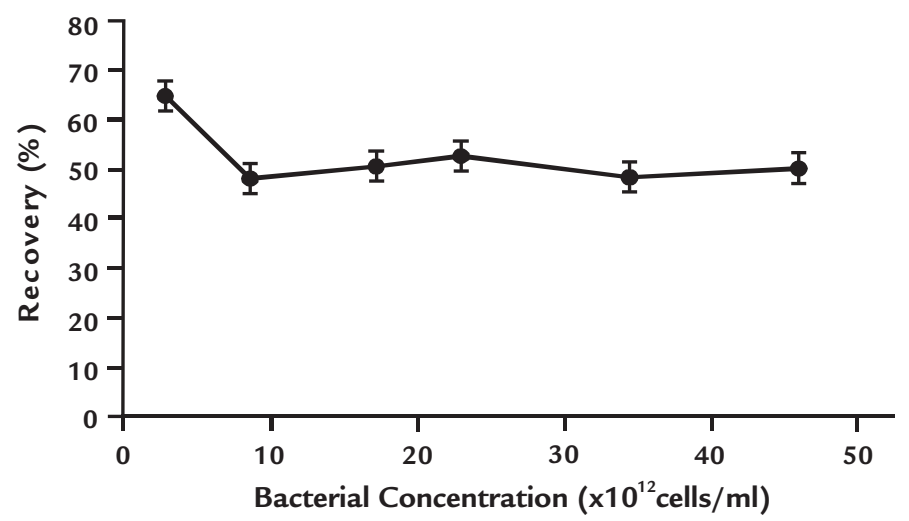

Figure 6

Effect of bacterial concentration on flotation recovery of cassiterite fines at $\mathrm{pH} 3$. 


\section{Conclusions}

Zeta potential results showed that $R$. Opacus cells were positively charged under acidic conditions $(\mathrm{pH}$ $<2.42$ ) and negatively charged under neutral and alkaline conditions, with an IEP at pH 2.42. Moreover, cassiterite particles showed and IEP at $\mathrm{pH}$ 5.8. The quantity of cells adsorbed onto the cassiterite surface was higher

\section{Acknowledgement}

The authors are grateful for financial at $\mathrm{pH} 3$ due to electrostatic attraction forces. Interactions of $R$. opacuscassiterite under acidic conditions changed the surface proprieties and charge to a degree dependent on the initial bacterial concentration: at 600 $\mathrm{mg}$ cells/L, the average surface charge was around 0 and contact angle was $80^{\circ}$. Current density and initial bacte- rial concentration were very important parameters in the electrolytic production of bubbles; high current densities and bacterial concentration promote the formation of small bubbles. The electroflotation test using $R$. opacus at the concentration of $2.87 \times 10^{12}$ cells $/ \mathrm{mL}$ (50 mg cells/L) at $\mathrm{pH} 3$ gave $64.5 \%$ cassiterite recovery.

\section{References}

support given by FAPERJ, CNPq, VALE and CAPES.

BOTERO, A. Bioflotation of magnesite, calcite and barite using Rhodococcus opacus as bioreagent. Catholic University of Rio de Janeiro, 2007. 130 p. (Ph.D. Thesis). (In Portuguese).

CHIPFUNHU, D., ZANIN, M., GRANO, S. The dependency of the critical contact angle for flotation on particle size-Modelling the limits of fine particle flotation. Minerals Engineering, v. 24, p. 50-57, 2011.

DIDYK, M.A., SADOWSKI, Z. Flotation of serpentinite and quartz using biosurfatants. Physicochemical problems of minerals processing, v. 48, n.2, p. 607-618, 2012.

DUBEL, J., SMITH. R.W., MISRA, M., CHEN, S. Microorganisms as reagents: the hematite system. Minerals Engineering, v. 5, p.547-556, 1992.

GOVENDER, Y., GERICKE, M. Extracellular polymeric substances (EPS) from bioleaching systems and its application in bioflotation. Minerals Engineering, v. 24, p. 1122-1127, 2011.

KUYUMCU, H. Z., PINKA, J., BIELIG, T. A novel process for sorting fine-sized sulphide minerals by biocoagulations. Transaction of Nonferrous Metals society of China, v.18, p.1473-1479, 2008.

MIETTINEN,T., RALSTON, J., FORNASIERO, D. The limits of fine particle flotation. Minerals Engineering, v. 23, p. 420-437, 2010.

NATARAJAN, K.A. Microbially-induced mineral flotation and flocculation: prospects and challenges. In: INTERNATIONAL MINERAL PROCESSING CONGRESS, 23. Proceedings... v. 1, p. 487-498, 2006.

PEASE, J., CURRY, D.C., YOUNG, M.F. Designing flotation circuits for high fines recovery. Minerals Engineering, v. 19, p. 831-840, 2006.

PECINA, E.T., RODRIGUEZ, M., CASTILLO, P., DIAZ, V., ORRANTIA, E. Effect of Leptospirillum ferrooxidans on the flotation kinetics of sulphide ores. Minerals Engineering, v. 22, p. 462-468, 2009.

QUIN WEN-QUING, REN LIU-YI, XU YANG-BAO, WANG PEI-PEI, MA XI-HONG. Adsorption mechanism of mixed salicylhydroxamic acid and tributyl phosphate collectors in fine cassiterite electro-flotation system. Journal Central South University, v. 19, p. 1711-1717, 2012.

RAO, K.H., SUBRAMANIAN, S. Bioflotation and bioflocculation of relevance to minerals bioprocessing. In: EDGARDO R. DONATI e WOLFGANG SAND (ed.). Microbial processing of metal sulfides, p. 267-286. 2007

SHARMA, P.K. Surface studies relevant to microbial adhesion and bioflotation minerals. Sweden: Lulea University of Technology, 2001. (Ph.D. Thesis).

SHAHBAZI, B., REZAI, B., JAVAD KOLEINI, S.M. Bubble-particle collision and attachment probability on fine particle flotation. Chemical Engineering and Processing: Process Intensification, v. 49, p. 622-627, 2010.

SHAHJAHAN KAISAR ALAM SARKAR, MD., EVANS, G., DONNE, S. Bubble size measurement in electroflotation. Minerals Engineering, v. 23, p.1058-1065, 2010.

Artigo recebido em 03 de outubro de 2012. Aprovado em 23 de julho de 2013. 